DOI https://doi.org/10.36059/978-966-397-158-2/21-40

\title{
EXPANDING THE SECURITY CONTENT IN MODERN CONDITIONS AND SPECIFICS OF ITS PROVISION
}

\section{Kormych A. I.}

\section{INTRODUCTION}

The current stage of civilizational development focuses on the category of «security». World security issues become key issues discussed by the UN General Assembly in February 2019. And the issues of national security necessitated amendments to the Constitution of Ukraine made by the Verkhovna Rada on February 7, 2019. This dictates the need for real steps to create normal conditions for life and social development. It is in this perspective, for example, that the Budapest Memorandum of 1994 and its consequences for Ukraine can be evaluated, especially since 2014, following the aggression against Ukraine by one of the signatories to this memorandum - the Russian Federation. Such events confirm that security needs real guarantees, not populist promises. Legal acts must clearly define mutual commitments to support security, and effective institutional changes must take into account the particularities of the modern era and the hybrid nature of ongoing processes.

The practical importance of a wide range of security issues has determined the scientific interest in these issues, which have become the subject of analysis in the writings of many professionals. Thus, foreign authors, and at different times, in particular, N. Machiavelli, K. von Clausewitz, Q. Wright, A. Toynbee, F. Fukuyama, S. Huntington, others investigated conflicts or extreme states - wars, characterizing their place in social development. Many contemporary Ukrainian scientists, such as V. Gorbulin, O. Dzoban, G. Kostenko, V. Lipkan, O. Lytvynenko, G. Pocheptsov, A. Shevtsov, and others, analyze the current state of security by offering complex methods of its provision. However, the dynamics of the processes taking place in the world and in individual countries need to be given further attention to these problems, to analyze them from the point of view of expanding the subject field of security itself, and accordingly the nature of models and mechanisms for its provision. 


\section{The new security content in terms of the functioning of its individual modes}

In terms of content, in security, according to the spheres of activity (in horizontal section) there are the following types: political, economic, environmental, social, informational, spiritual, military and other.

The basis for constituting types of security is a set of objective and subjective prerequisites: the needs of people, social groups, society, state, international community to preserve and develop themselves and vital social and natural values and objects; expanding the range of hazards and threats, risks and challenges; awareness of the vulnerability of people, their vital interests; political and legal recognition and consolidation of security; availability of appropriate concepts, strategies, plans.

The continual expansion of security content in accordance with changes in human life conditions should be noted. Security is a multidimensional concept. However, the dynamics of the elements of its structure have a specific historical meaning and are linked to systemic changes. Therefore, the definition of diversity and priority of security is changing in time and space and serves multiple concepts, due to the different modes of operation of this system.

The main modes of functioning of the security system are traditionally determined by the following: peacetime, high readiness, state of emergency, martial law. These modes can be implemented nationwide, regionally or industry-wide. They may apply to both individual states and their associations and coalitions.

The operation of the security system in peacetime means the existence of normal conditions for the operation of security systems in the absence of threats to the national interests of countries, the needs of the unions of states and their practical implementation. In this mode, security entities carry out: work on forecasting, detection, risk assessment, prevention of their transformation into threats; neutralization of all kinds of threats to the national interests of the states or the interests and needs of the unions of the states; developing, approving and adjusting security plans and programs implemented in accordance with the procedure established by law in the event of a threat to national or inter-state interests; organizational support, including work on recruitment, training and improvement of personnel in various security spheres; control over the level and quality of implementation of strategic programs.

The operation of a security system on alert is its activity in the escalation of dangers and threats to national or interstate interests. Under this mode, security system operators take additional measures to eliminate the dangers, 
minimize the effects of their escalation, to prepare forces and means to counteract real and potential threats.

The presence of real threats to national or interstate interests despite prevention measures indicates the need for a security system to operate in a state of emergency. In such cases, mobilization of forces and a complex of means for counteracting and overcoming threats, either at the national or international levels, takes place to counteract the threats, localize and eliminate them.

A martial law is a kind of state of emergency, its radical form. It is about the realization of military threats that require the use of military force to neutralize and destroy them. In this mode of operation, the security system becomes, first of all, a system of military security. And in such circumstances, the introduction of a state of emergency or martial law for a certain period or in certain territories is possible, and sometimes necessary. These are the circumstances in Ukraine at the end of 2018 in the face of real aggression of the Russian Federation and escalation of threats in connection with the situation in the Sea of Azov, when 24 Ukrainian sailors illegally became prisoners of the Kremlin, which forced to enter a martial law regime for a limited period in a number of areas ${ }^{1}$.

Under all modes, security laws are manifested - the speed of response of security system actors to threats must exceed the speed of their formation and maturation, and the activity of these entities should be directed not simply to the cessation, localization, elimination and destruction of dangers and threats and, above all, to prevent and neutralize the causes that generate them, that is, to prevent the emergence of threats.

Therefore, the security system has a complex structure, each element of which has a specific meaning and performs specific functions to meet the relevant needs of existence and the effective functioning of the system. The normative nature of the relationship within this system is determined by clearly formulated tasks that it is intended to solve (the objective component), as well as the tasks that are imposed from the outside (the subjective component). A security system is a holistic, complex mechanism that interacts with other subsystems continuously. System security is manifested not only in the relationship between its elements, but also in the interaction of the system with the environment.

The concept of security system and system of security provision should be distinguished. The first is a functional system that reflects the processes

\footnotetext{
${ }^{1}$ Про введення воєнного стану в Україні: Указ Президента України від 26 листопада 2018 р. № 393/2018 (Указ затверджено Законом № 2630-VIII від 26.11.2018 із застереженням). Голос України. 28.11.2018. № 226.
} 
of interaction of interests and threats, and the second is an institutional system of bodies, forces, tools designed to solve security tasks.

An important prerequisite for ensuring the integrity and effectiveness of the security system is the proper definition and consideration of the organizational principles for its construction and operation. These may include principles such as: sufficiency focused on the adequacy of the system for foreseeable (potential) hazards and threats; optimality, which reflects the relevance of the security system and its costs to the real capabilities of states and societies; correlations that provide feedback and the ability of control entities to operate effectively at all levels and elements of the security system, with a view to improve them in the face of emerging threats and tasks that change over time and space; the coherence of actions of all actors and security forces, combined with the principle of responsibility for decisions made and the results and consequences of the process of their implementation.

These principles are particularly clearly manifested in extreme, radical situations that the security system is experiencing, especially in wars. At various stages of the history of mankind during the wars were resolved contradictions that have accumulated between the states; a new model and structure of international relations, consistent with the current political, economic and military balance was established; coalitions, alliances and blocs were adjusted. Military power was regarded as the most important component and factor in the strength of the state and the preservation of power. For a long time, the only one correct was the statement made by N. Machiavelli that A Prince ought to have no other aim or thought, nor select anything else for his study, than war and its rules and discipline; for this is the sole art that belongs to him who rules, and it is of such force that it not only upholds those who are born princes, but it often enables men to rise from a private station to that rank. And, on the contrary, it is seen that when princes have thought more of ease than of arms they have lost their states. ${ }^{2}$ That is, government and power were viewed solely through the lens of military success and were associated with the use of force and coercion in their radical format.

For a long time, the views of the war were dominated by the ideas of the German military theorist Karl von Clausewitz, in particular, in his preface to the treatise On War, that war was nothing more than a continuation of state policy by other means ${ }^{3}$. That is, wars were seen as a normal form of

\footnotetext{
${ }^{2}$ Machiavelli N. The prince. Translated with an introduction by H.C. Mansfield. 2nd ed. Chicago: The University of Chicago Press, 1998. P. 58.

${ }^{3}$ Клаузевиц К. О войне. В 2 т. Москва: АСТ. Санкт-Петербург: Terra Fantastica, 2002. T. 1. C. 11 .
} 
interaction of subjects in international relations. In doing so, von Clausewitz emphasized the social nature of armed conflict, noting that «war is an act of human communication». Accordingly, war refers «to the field of social life. It is a conflict of great interests, which is resolved by bloodshed, only in its last difference from other conflicts. «Politics, in turn, «is a war-bearing bosom; politics already contain the hidden features of war, just as the appearance of a living creature lies in its embryo» ${ }^{4}$.

Thus, in spite of the policy-based nature of the war, public policy is still largely related to military considerations. After all, an important task of foreign policy was the creation of favorable international conditions for the victory in future armed conflicts, first of all, through the creation of effective coalitions of their own.

The transformation of views on the war has certainly contributed to the most violent conflict in human history - World War II. The enormous human and material losses have led to a different look at war as a method of solving the problems of international relations. Thus, the English philosopher and historian A. Toynbee emphasized that war is essentially the result of the inability of a political solution to the conflict. He noted that war was «a physical test of power in which conflict of interest or difference of opinion is resolved by brute force. It would be closer to truth to say that war is a payback for the failure of diplomacy» ${ }^{5}$.

The recognition of the nonlinearity of the link between public policy and war as its instrument should be added, since war is the product of a complex set of objective and subjective factors. In particular, as early as 1942, American international scientist Q. Wright noted that «wars result from many combinations of changes in different relationships - technological, physical, sociological, and intellectual. There is no single cause of war. The world is balanced between many forces. Changes in some particular forces (trends, movements or political goals) may, in one case, lead to war, but in other circumstances, similar changes can lead to peace ${ }^{6}$.

On such ideological postulates in the second half of the twentieth century a negative attitude to the military means of conflict resolution began to form in the world politics, which contributed to the efforts of states to prevent a new world conflict, and the development of international legal instruments for conflict resolution, in particular within the UN, and the threat of a global war on the use of nuclear weapons, which would mean the end of

\footnotetext{
${ }^{4}$ Ibid. p. 163.

5 Toynbee A. J., Ikeda D. The Toynbee - Ikeda Dialogue: Man Himself Must Choose. Tokyo: Kadansha International, 1976. P. 186.

${ }^{6}$ Wright Q. A Study of War. In 2 vols. Chicago: University of Chicago Press, 1942. Vol. 2.
} P. 1284. 
civilization. Therefore, the emphasis shifted to the incentives for joint efforts on disarmament, restrictions on the use of military force, etc. Particular successes in the implementation of the new model of state interaction were achieved between the mid-1970s and the mid-1980s. This period became known as the «discharge of tension». However, the next stage in the development of the security system, both international and national, witnessed an increase in threats and a new range of use of military force as a means of conflict resolution, with both internal and external.

The collapse of the communist regimes has caused an outbreak of internal armed conflicts and the use of force at the international level, in particular in the territories of the former USSR, Yugoslavia, Albania, some of which have not yet disappeared or have become so-called «frozen» conflicts. Examples include the war in Bosnia and Herzegovina, the conflicts in Moldova (Transnistria), Georgia (Abkhazia and South Ossetia), Tajikistan, the Armenian-Azerbaijani confrontation (Nagorno-Karabakh), etc. And today Ukraine can be included to this list, where for more than 5 years there has been an armed conflict with the participation of the Russian Federation, which includes annexation of Crimea and hostilities in the east of Ukraine.

It should be noted that there are different theories of conflict. Thus, according to one of them, conflicts arise on the so-called «lines of division between civilizations», where there is a clash between different cultures and systems of values. In particular, characterizing this type of armed conflict, American political scientist S. Huntington notes that «fault line conflicts are communal conflicts between states or groups from different civilizations. Fault line wars are conflicts that have become violent. Such wars may occur between states, between nongovernmental groups, and between states and nongovernmental groups $\rangle^{7}$.

Against the backdrop of the analysis of the situation, theories emerged about the formation of a new "arc of instability and conflict» from the Balkan Peninsula to Afghanistan, where local and regional conflicts were resolved by military means in the form of peacekeeping operations to maintain peace or to compel peace or to cease armed violence. Such operations are mainly carried out under the mandate of international organizations, first and foremost the UN. History provides both positive and negative examples of the use of force in international relations to solve complex problems and establish peace in a particular region. So, successful is the international operation in Iraq, dubbed «Desert Storm», which restored

${ }^{7}$ Huntington S. P. The Clash of Civilizations and the Remaking of World Order. New York: Simon and Schuster, 1996. P. 252. 
Kuwait's independence captured by Iraq during the aggressive war, which had catastrophic consequences for the aggressor himself ${ }^{8}$.

The liquidation of Saddam Hussein's regime has significantly reduced the level of further aggravation of the military and political situation in the region, although it has not solved all the problems. Of course, not all peacekeeping operations are successful. So, the peacekeeping operation in Somalia was unsuccessful, where inter-tribal war actually led to the collapse of statehood. Operations in Africa, in the Great Lakes region, where fierce ethnic wars have unfolded, have proved ineffective. This is indicative of a downward trend in the role of military power, which has often been unable to resolve conflicting political problems.

A similar situation has arisen from time to time in different years. For example, in the 1970s, the US was defeated in Indochina, and the USSR was defeated in Afghanistan in the 1980s. With overwhelming military power, these states could not win and achieve their political goals in these regions. The trend continued in the 1990s: the result was the repeated defeat of the Russian army in Chechnya (Ichkeria). Another manifestation of this tendency was the emergence of a kind of deadlock in a number of local conflicts, when prolonged hostilities exhausted all parties involved and did not lead to any victory. However, the problems of international legitimation of military intervention in the modern world in the context of local conflicts of different internal and external origin, put on the agenda of international relations a number of complex and ambiguous issues. In particular, this concerns situations of mass violations of human rights by criminal authorities. The actions of the United Nations are often ineffective, especially given that there are fundamental differences in the assessment of such regimes among the five permanent members of the UN Security Council or are themselves parties to the conflict. Such situations stimulate discussions on UN reform.

In some cases, the use of force has created new problematic situations. Examples include military intervention on various grounds and with substantially different levels of international support, such as the NATO operation against the Milosevic regime, the Afghanistan war, the operation of the international coalition against Saddam Hussein in Iraq, the RussianGeorgian war of August 2008, the creation of a closed-air regime in Libya during the overthrow of the Gaddafi regime, hostilities against IS in the Middle East, military intervention in civil strife in Syria and several other events on the geopolitical map with diametrically different positions of the participating parties and those who support them.

\footnotetext{
8 Современные международные отношения. Под. ред. А. В. Торкунова. Москва: Российская политическая энциклопедия (РОССПЭН), 1999. С. 68-72.
} 
All these military and political events, regardless of their degree of completion, highlight many of the problems and contradictions that exist in the system of international relations and in international organizations at the global level, such as the UN, which are designed to regulate international conflicts. The most researched from this point of view is the war in the Balkans. One of the important conclusions of this war is, first of all, the confirmation of the need for self-restraint and coordination of efforts in military-political relations.

The involvement of nuclear powers on different sides in the war with the Milosevic regime: Russia - on the one hand, the United States, Britain and France - on the other, fortunately, did not lead to the use of nuclear potential and nuclear status. But the very fact of having weapons of mass destruction among the parties to the conflict is too dangerous and threatening, demonstrating the urgent need for self-restraint and rigid self-control.

At the same time, these events confirmed the effectiveness of coordination of actions, joint efforts of states to solve difficult situations. The NATO nations have achieved a convincing victory by fixing the Rambouillet talks. This reaffirmed the importance of joint action within a military and political structure such as NATO for the effective use of military force to achieve humanitarian goals.

However, the development of the world political process at different stages and in different regions gives much evidence of the tendency that political and economic sanctions and diplomacy may be more effective than direct military pressure and armed violence. An example is the collapse of the communist regimes in Central and Eastern Europe and the collapse of the Soviet Union, which have resulted from the excessive burden of military spending, will lose the race to ensure the proper material standard and quality of life of the population and the result of changes in ideological values.

The diminishing role of the military way of resolving conflicts within the international relations system did not mean a complete rejection of it. Power methods are used both in the traditional version and in new forms of various peacekeeping operations. However, the situation in the world at the turn of the XX-XXI centuries also showed new trends: orientation towards the use of a large arsenal of peaceful ways of resolving conflicts with emphasis on the priority of human rights, protection of its freedoms and creation of normal conditions for existence and development. This contributed to the further democratization of the entire system of international relations, the expansion of the institutional framework for cooperation and the establishment of civilizational communications, and the expansion of a secure space in international relations. 
To be true, the latest trends have given rise to certain illusions that have weakened security both internationally and in terms of national security in individual countries. In particular, it concerns the situation in Ukraine related to the annexation of Crimea and the beginning of the Russian aggression in the East of Ukraine since 2014. This has a number of negative effects, which does not contribute to strengthening security within the international relations system. The world community has proven unable to prevent a range of forms of violence, including hybrid wars, the overall crime rate and the use of repressive methods that threaten human security.

This puts states before choosing a model for ensuring their own security. There are two alternatives: to integrate into a new model of international relations that eliminates the very sources of potential conflict; or stay in an old, confrontational model where military power and the right of a stronger army play a major role. The events of recent years demonstrate the devastating fallacy of implementing the second approach, in particular, the present-day Russian Federation, forcing Ukraine to seek opportunities for a new international order and security that is capable of providing real security guarantees and maintaining stability in international relations, taking into account national interests of all parties. Ukraine's strategic intentions to join NATO are clear evidence of such a search. And such a course was confirmed by the decision of the Verkhovna Rada of Ukraine of February 7, 2019 on amendments to the Constitution aimed at consolidating the strategy of achieving EU and NATO membership?

Along the way, new tasks are emerging or new content is being provided to existing security and support tools in an extremely complex modern environment, when conflicts intersect in different areas. The ambiguity of the conditions of activity accordingly requires similar ways and means of talking the emerging issues.

\section{Hybrid nature of modern conflicts}

Confrontation in today's environment focuses on new priorities, demanding a comprehensive approach to security. This is especially true of the information sphere, which has become a field of active struggle in the face of hybrid forms of confrontation and conflict.

The events of recent years have convincingly demonstrated that domination in the information field enables successful achievement of foreign and domestic policy goals. Obtaining information advantage is seen

\footnotetext{
${ }^{9}$ Про внесення змін до Конституції України (щодо стратегічного курсу держави на набуття повноправного членства України в Європейському Союзі та в Організації Північноатлантичного договору): Закон України від 07.02.2019 р. № 2680-VIII. Офіційний сайт Верховної Ради України. URL: https://zakon.rada.gov.ua/go/2680-VIII.
} 
as an effective and promising tool to achieve political goals in situations where the use of force is impossible or impractical. Information warfare moves from the military and technological sphere to the formation of ideological stereotypes through the methods of political manipulation and linguistic programming. In modern discourse, the latest concepts are widely used: fakes, trolls, bots, etc.

Until recently, the United States led in the propaganda support of political goals, in the last decade the information and expansionist activities of the Russian Federation have intensified, which is large-scale, costly and rather aggressive. So, the US and a number of European countries have been forced to investigate Russia's interference with information technology into electoral processes, and Ukraine has felt the devastating impact of such activities, especially since 2004.

The main objectives of information excellence are to target the adversary with prepared or false information or misinformation, as well as to limit the ability to obtain reliable information about real plans and intentions. An important part of the information war is the creation of favorable public opinion in the country around the operation. The range of tools used varies from traditional propaganda and agitation to the use of the latest technical capabilities, including social networks, to create the desired virtual reality, manipulation of consciousness. Modern researchers, in particular, G. Pocheptsov, A. Shevtsov, and other refer the changes in consciousness to global threats in the process of constructing the future, because such changes are capable of fulfilling both positive and negative functions. So G. Pocheptsov emphasizes that modern «global projects are aimed either at a significant correlation of mass consciousness, or to its complete change» ${ }^{10}$. A. Shevtsov, warning of the possibility of such threats, argues that «scenarios of the future should plan to preserve civilization» ${ }^{11}$.

The combination of technological innovations with methods of information-psychological action allowed developing the concept of «effects based operations». The meaning of such operations is the ability to abandon the physical destruction of the enemy, and to change his behavior, psychologically adjust him to the possibility of gaining capitulation and giving up armed resistance. The RF applies the same nowadays. New tools do not exclude the use of force, but focus on tools of psychological pressure.

${ }^{10}$ Почепцов Г. Глобальні проекти: конструювання майбутнього. Київ: Український центр політичного менеджменту, 2009. С. 6.

11 Шевцов А. І. Майбутнє людства необхідно спланувати: глобальні загрози і довгострокова стратегія розвитку України. Стратегічні пріоритети. 2007. № 1(2). C. 188 
Diplomacy, economic and political influences are also used to change attitudes and behavior. The use of such soft power becomes more effective than direct military pressure in today's international relations.

It should be noted that such actions are not a completely new invention of humanity. Such a hybrid approach, focused on the behavioral motivations of the enemy, suggested in his time Karl von Clausewitz, emphasizing the importance of psychological aspects of war. But the use of innovative techniques and technologies gives such actions scale and effectiveness.

Such effects based operations have a number of advantages: integrated planning provides for the integration of military and non-military aspects, effectively selects goals and prioritizes them, identifies enemy weaknesses; does not destroy, but uses the infrastructure of the enemy; all sources of power of their own state are used optimally - political, economic, military and diplomatic; encourages the interaction of command with other actors in the campaign, thereby reducing the likelihood of errors and inconsistencies; innovative forms of action, such as networking, are introduced.

The information component of the concept of effects based operations has been used quite successfully in the Second Iraqi War. During this campaign, the psychological war against Iraq was fought through 50 million leaflets and hundreds of hours of radio and television broadcasting. At the same time strategies of suppression of communication systems of the enemy were applied, misinformation was used. All this was complemented by the Allied military operations in the framework of air and ground operations, during which the Iraqi military and political leaders and terrorist group leaders were destroyed. It accelerated achievement of goals even in difficult natural conditions and in a situation of specific guerrilla struggle.

From a military and technological point of view, the Second Iraqi War achieved short-term goals in the shortest possible time and with minimal cost. However, there were no long-term political goals, especially after the formation of IS units in Iraq: there is no sustainable peace and democratic regime in Iraq. The Second Iraq War was in fact the first campaign that was fully planned based on the concept of result-oriented operations. But it has shown that even cutting-edge technology alone does not guarantee the achievement of political goals, especially strategic ones, not just temporary ones.

Realizing this, a number of result-oriented operations theorists began to turn to Clausewitz's ideas, to draw on Lenin's understanding of war as a natural form of politics. Similar views dominate in Putin administration, justifying the war, seeking to portray it in the eyes of Russian and world public opinion as the usual means of regulating international relations. However, not taking into account that the same Karl von Clausewitz 
regarded the war solely as an extreme, marginal and in this sense exclusive phase of the political struggle.

This is the approach that Russian politicians and authorities have demonstrated in their relations with Ukraine since March 2014. The information war of previous years is complemented by military presence and efforts to present events as a natural result of Ukraine's internal conflicts and justified actions by Russia. From the logic of this approach, the idea of the possibility of changing the world order will follow. Speech by Prime Minister of the Russian Federation D. Medvedev at the Munich Security Conference in February 2016 fits in with a similar understanding of modern information operations. In fact, he declared such a war with the West in the form of a new variant of the modern Cold War.

Such statements force countries to create mechanisms to counteract information interventions that can weaken security. Moreover, they find evidence of the Russian cyber-intervention in electoral processes in the United States, France, Germany, the Netherlands, which are being investigated and regarded as real threats to the national security of countries. Similar questions have arisen in the UK about preparing public opinion for a decision to leave the EU. Instead, there is a need for counter-measures similar to the creation of a US NSA Task Force on Counteracting Russian Threats in Cyberspace, announced at the 2018 Annual Aspen Security Forum.

For Ukraine, the information war, cyberattacks on the part of the Russian Federation has long been a reality that needs active counteraction. The importance of the formation and continuous improvement of an effective state-legal mechanism in the field of information security has been emphasized by scientists for a considerable period. ${ }^{12}$

However, adequate policy response has not taken place, despite the fact that information wars have become an integral part of modern hybrid forms of war. They create no less tension in international relations than traditional armed confrontation, the level of which has declined somewhat since the second half of the twentieth century.

Humanity in the first half of the twentieth century failed to create a credible security system: two world wars and bloody revolutions claimed the lives of more than 100 million people and disabled more than 40 million. World War II alone, in monetary terms, cost more than $\$ 662$ billion. All of this has led to a rethinking of ways and methods of conflict resolution with the use of weapons, which have become increasingly devastating.

12 Кормич Б. А. Організаційно-правові засади політики інформаційної безпеки України. Одеса: Юридична література, 2003. 472 с. 
The peculiarity of the second half of XX century and the beginning of the 21 st century is that the global community has been able to prevent the major threat to international security, and at the same time to the national security of individual countries - the threat of unleashing a new, this time, fusion war capable of destroying all life on Earth. Bans and restrictions have been introduced on a number of weapons of mass destruction, such as nuclear, chemical, and bacteriological. But even stockpiling, as well as the destruction of such weapons, involves not only enormous financial costs but also threats to the security of the public and the environment.

In addition, prohibited weapons, such as vacuum bombs, anti-personnel landmines, or even chemical weapons, are occasionally used in regional and local conflicts, including military ones. For example, similar questions have arisen regarding Syria on April 5, 2017, when more than 70 people were killed in the sarin gas bombardment, 27 of which were women and children, and more than 540 were found in hospitals with long-banned chemical weapons poisoning. These issues were discussed at the UN Security Council, though without decision-making. The answer was an American rocket attack on the Syrian Air Force base, from which aircraft with illicit chemical weapons lifted. Therefore, it can be stated that the world community of the second half of XX - early XXI century made a major step forward in the direction of democracy, the protection of human rights and fundamental freedoms, and the improvement of economic and social conditions of people. But it has not been able to prevent fully violence in its various manifestations, that is, to ensure security of development.

In this respect, security is also a common crime in the world. Since the 1980 s, crime has increased by $5 \%$ annually in the world and has become an organized feature ${ }^{13}$. The initiators and perpetrators of crime are organized groups that have the latest weapon systems, communications, eavesdroppers, etc. Such criminal groups create skilled staffs, operational services, have predesigned crime plans. Such «criminal communities» are distinguished by a high level of organization, detailed preparation of criminal activities, broad financial resources, a hierarchy of management and discipline. The recent trend is the rapid growth of transnational criminal organizations with the participation of citizens of several countries, criminal activity in a number of countries, the organization of crimes that violate international obligations and international law. Such transnational crime groups are quickly adapting to new circumstances and often act as an additional provoking factor for conflicts, including by escalating international tension, deteriorating international cooperation, provoking local, regional, and international conflicts.

13 Современные международные отношения. Под. ред. А. В. Торкунова. Москва: Российская политическая энциклопедия (РОССПЭН), 1999. С. 111-113. 
The most dangerous form of crime in the world today is international terrorism. The goals of terrorism are varied: changes in political structure, leadership or course of the country; imposing sectarian, radical nationalist, fundamentalist and other beliefs on people; loosening the state of stability in society, intimidation of the population, provocation of hostilities, release of participants in terrorist acts, etc. The arsenal of terrorist methods and means is also broad: assassinations of political leaders, hostage-taking, undermining of important civic objects and institutions; recruitment, financing, training of mercenaries and their use in military and terrorist acts; capture of airplanes, television and radio centers, infrastructure; illegal television and radio and more. Back in the early 90's of the twentieth century. around 500 terrorist organizations and groups of various extremist backgrounds have been active in the world. In the course of 10 years, they have committed more than 7,000 terrorist crimes that have killed more than 11,000 people ${ }^{14}$.

But their existence was seen as part of the political landscape of only a few troubled countries and regions. Only after the September 11, 2001, terrorist attacks in the United States were considered a major security threat to all. The world has realized the real threat to security from terrorist networks that have spread to different countries, even the most stable ones. Today, a major threat to security is, in particular, the activities of a terrorist organization such as the Islamic State, which has already surpassed the scale of al-Qa'ida's crimes.

A serious threat to the international community is the crime associated with drug trafficking. The number of such crimes in the world is growing at such a rapid rate that this process is being compared to an epidemic. In the first five years of the 2000s, the number of drug-related crimes in the world increased in 5 times. A characteristic feature of the modern drug business is going beyond national borders, organization of illegal international traffic, covering almost all countries of the World. Powerful groups have been formed that have a wide network of not only trade but also manufacturing enterprises, their own laboratories, specially trained staff. The international narcotics business is making a huge fortune for its owners. For example, the total annual income of the American Mafia from drug smuggling is more than $\$ 1$ billion, which exceeds the national budgets of several countries. Concentrating money in the hands of drug dealers creates a problem of money laundering, which causes new crimes. The consequence is the harm to the health of a large number of people, reducing their social activity, deterioration of the gene pool of the population. Possession of large sums of money allows to exert pressure on representatives of the authorities, law

14 Шерпаев В. И. Военная политика современной России. Екатеринбург: Изд-во Уральского университета, 2007. С. 127. 
enforcement agencies, mass media, which loosens the stability of society, undermines its security.

Security threats are posed by crimes that infringe upon the personal rights of citizens: exploitation of child labor, trafficking in human beings, the spread of pornography, the forcible abduction of persons for exploitation or ransom. This kind of crime takes on new forms, often hidden and therefore difficult to recognize. In the context of conflicts in different regions, such activity is significantly intensified, which is also felt by Ukrainian society today. The military conflict in the east of Ukraine, supported by the actions of the Russian Federation, stimulates similar criminal forms that create new security threats for individuals and society as a whole.

A new and dangerous type of crime is illegal high-tech operations involving the use of a network of computers, telecommunications equipment, and other types of high-tech technology. These are numerous variants of cybercrime, illegal cloning experiments with the threat of gene pool, and information and psychological manipulation of human consciousness, and more.

The creation and activities of private armies, such as the private military campaign Wagner in the Russian Federation, which are used to obscure the participation of regular military units in other countries, can be included in the category of criminal acts today. This structure was used by the Russian Federation in eastern Ukraine, Syria, to deny its direct involvement in military operations. Such a phenomenon, in our opinion, effectively erodes Weber's understanding that any territorial political organization «will be called 'state' insofar its administrative staff successfully upholds the claim to the monopoly of the legitimate use of physical force in the enforcement its order» ${ }^{15}$, which has been extended by F. Fukuyama thesis that state's essence is nothing more than power of enforcement and possibility to send somebody in uniform and with weapons ${ }^{16}$. Because, the failure to grant such monopoly is not merely issue of a weak state under attack, but to the great extend it is also the issue of the state inspiring such «private» military campaigns, so far the latter can not grant the same level of control and responsibility for its «private» armed proxies as it can grant in case of its military forces. After all, it testifies to the inability of some subjects of world politics to solve civilly complex political problems in the present conditions and, in turn, could lead to the transformation of entire states into terrorists, if such a tendency dominates and the uncontrolled field of aggression dominates. And it is a great threat to the whole system of international relations.

\footnotetext{
${ }^{15}$ Weber M. From Max Weber: Essays in sociology. London: Routledge, 1991. P. 78.

${ }^{16}$ Fukuyama F. State Building: Governance and World Order in the Twenty-First Century. London: Profile Books Ltd, 2004. P. 6.
} 
Thus, the world community at the beginning of the XXI century faced new security challenges and threats, both nationally and regionally or globally. Many of the emerging threatening occurrence and phenomena are directly related to the effect of globalization. The point of view is widely held that the emergence of international threats is the result of an archaic and asymmetric response to globalization by world outsiders unable to fit into the new rules of the game. In many interpretations, the situation is described as a clash of global political and socio-economic processes and new globalizing institutions with reactionary traditionalist ideologies that have «mutated» and their organizational practices. Threats represent «all Western» denial and / or the quintessence of primitive anti-globalization. But such interpretations are too limited and do not take into account the positive results of globalization, focusing only on the negative aspects of the process. They categorically oppose globalization and glokalization and are unable to take into account the positive of each of these processes.

In some cases, the explanation, for example, of international terrorism is based on an analysis of the specific role of authoritarian regimes in particular regions, in particular, in the Middle and Middle East. According to similar interpretations, the victory of national patriotic forces is possible only if any support to the non-patriotic ruling regimes ceases, and terror acts as a means of achieving this goal. However, a significant number of regimes today are hybrid in nature, not being a purely authoritarian variant, which creates certain problems in assessing their behavior and in their attitude to the environment.

Today, in order to overcome threats to national security, as well as international security, a system capable of integrating the resources of both individual states and the international community as a whole must function effectively. It should be based on the principles and norms of international law and national legal systems and combine international and national institutional capacities. The public sector should also be involved in the public sector in the form of public institutions of different profiles and levels. Only such an integrated approach will guarantee success in creating the conditions for the secure existence of man, the state, society, and in return, the global community as a whole and democratic progress.

The most comprehensive approach to security issues was announced by Ukrainian researchers such as V. Gorbulin, O. Lytvynenko, O. Dzoban, G. Kostenko, V. Lipkan, and many other national security experts who analyzed in detail the theory and practice of implementing security strategies ${ }^{17}$.

17 Горбулін В. П., Літвіненко О. В.Національна безпека: український вимір. Київ: Інтертехнологія, 2008. 104 с.; Національна безпека України: концептуальні засади та світоглядний сенс. Ред. О. Дзьобань. Харків: Майдан, 2007. 284 с.; Теоретичні основи та елементи національної безпеки України. Ред. В. Ліпкана. Київ: Текст, 2003. 600 с. 
Despite such complexity, the main focus is on military security, preserving the integrity and independence of the state, protecting its national interests. The new military doctrine of Ukraine introduced by the Presidential Decree of September 24, $2015^{18}$ and the new Law on National Security, adopted by the Verkhovna Rada of Ukraine on June 21, $2018^{19}$, which define a new military doctrine of Ukraine, confirm this approach to understanding the categories of «national security» and «international security» content, forms, directions and methods of security protection in modern conditions.

The corresponding tendencies of security understanding were also enshrined in the amendments to the Constitution approved by the Verkhovna Rada of Ukraine, which should become a guaranteed security strategy of development of society and state and integration of Ukraine into the world security processes on the basis of democratic transformations. And it is important to follow the chosen course despite the changes in the state leadership as a result of regular election campaigns in the country presidential or parliamentary. The consistency of foreign and defense policy is the basis for the security and success of democratic reforms.

In spite of the nonlinear nature of the development and the multiplicity of such processes, the analysis of the factors of influence on them gives effective tools for the real creation of safe conditions for the existence of man, society, state and the world community in the present conditions and advancement of the world political process in the direction of civilizational progress. Institutional, regulatory and procedural transformations, both nationally and internationally, must be subject to this goal. This is the path Ukraine is taking, strengthening its own security, contributing to the international security system and gradual integration into the European security area.

Complex problems of interstate relations and world politics were discussed at the 55th Munich Security Conference, held on February 15-17, 2019 with the participation of heads of many states, ministers, representatives of the world political elite. The agenda included issues of world security, competition of major powers, the actual withdrawal of the Russian Federation and the US response to the treaty on medium - and lowrange missiles, Russian aggression in Ukraine, environmental security, challenges of the North Stream 2, and several other important security issues. The success or failure of dialogue between states largely depends on determining the strategies and prospects for the development of the global

${ }^{18}$ Про рішення Ради національної безпеки і оборони України від 2 вересня 2015 року «Про нову редакцію Воєнної доктрини України»: Указ Президента України № 555/2015 від 24.09.2015. Офіиійний вісник Президента Украӥни. 2015. № 22. С. 19. Ст. 1291.

19 Про національну безпеку України: Закон України від 21 червня 2018 p. № 2469-VIII. Відомості Верховної Ради України. 2018. № 31. Ст. 241. 
political process. Because every such step is able to both strengthen security and produce new security threats. Therefore, common sense should be encouraged to preserve the life and civilization progress of mankind.

\section{CONCLUSIONS}

Researchers interpret the content of security in ambiguous manners. Supporters of a «broad» interpretation of the subject field of security characterize the expansion of the security space in four dimensions. The first one concerns the extension of security «down from states to individuals». The second embodies the vision of «upward from states to the biosphere.» The third concerns the horizontal aspect - military, political, economic, social, environmental, human security, etc. The fourth dimension refers to political responsibility for security, which is «scattered» in all directions: from states upwards to international institutions, and downwards to regional and local authorities, non-governmental organizations, public opinion, the press, etc.

Expanding the content of security provides the ability to withstand the current challenges and threats, to create a secure environment that guarantees the development and deepening of democracy.

The diverse nature of the threats determines a wide range of security activities: military-defense, information, environmental, economic, financial, socio-demographic, energy, ethno-national, religious. Thus, it can be concluded that expanding the content of security in modern conditions and the hybrid nature of the processes of formation of security threats require the definition of indicators, incentives, etc. to justify the prospects for the development of the global political process and to form on this basis a safe environment for successful implementation of progressive changes in different spheres of life. Creating new models of national and international security that can meet the current threats and challenges is an important factor in successfully solving the complex challenges of democratic transit and the further development of democracy. The main thing in this case is the introduction of promising models and real programs for the safe functioning of humanity into practice. The dynamic era of democratic change contributes to these challenges. Through reforms, Ukraine can make the most of the opportunities provided, take a prominent place in the implementation of this progressive trend, pursuing a course of strengthening national and international security and creating favorable conditions for sustainable development.

\section{SUMMARY}

At present, the content of the security concept has expanded significantly, covering different spheres and levels of life. Security issues have become key in functioning of many international and national 
institutions. The security system as a functional reflects the interaction of interests and threats, and the security system as an organizational and institutional system creates mechanisms for protection and prevention of threats. The specificity of security in the context of the development of democracy, above all, needs to improve the legal framework both in the aspect of international law and in the framework of national legislation. Regulatory and procedural features are determined by specific security regimes. The hybrid nature of modern processes dictates the need for a comprehensive approach to the design and regulation of the functioning of a complex security system and models of its provision. The specific experience of countries indicates the need to increase the effectiveness of the security system for the implementation of democratic reforms.

\section{REFERENCES}

1. Fukuyama F. State Building: Governance and World Order in the Twenty-First Century. London: Profile Books Ltd, 2004. 256 p.

2. Huntington S. P. The Clash of Civilizations and the Remaking of World Order. New York: Simon and Schuster, 1996. 367 p.

3. Machiavelli N. The prince. Translated with an introduction by H.C. Mansfield. 2nd ed. Chicago: The University of Chicago Press, 1998. $184 \mathrm{p}$.

4. Toynbee A. J., Ikeda D. The Toynbee - Ikeda Dialogue: Man Himself Must Choose. Tokyo: Kadansha International, 1976. 348 p.

5. Weber M. From Max Weber: Essays in sociology. London: Routledge, $1991.514 \mathrm{p}$.

6. Wright Q. A Study of War. In 2 vols. Chicago: University of Chicago Press, 1942. Vol. 2. 1552 p.

7. Горбулін В. П., Літвіненко О. В. Національна безпека: український вимір. Київ: Інтертехнологія, 2008. 104 с.

8. Клаузевиц К. О войне. В 2 т. Москва: АСТ. Санкт-Петербург: Terra Fantastica, 2002. T. 1.558 c.; T. 2.574 c.

9. Кормич Б. А. Організаційно-правові засади політики інформаційної безпеки України. Одеса: Юридична література, 2003. $472 \mathrm{c}$.

10. Національна безпека України: концептуальні засади та світоглядний сенс. Ред. О. Дзьобань. Харків: Майдан, 2007. 284 с.

11. Почепцов Г. Глобальні проекти: конструювання майбутнього. Київ: Український центр політичного менеджменту, 2009. 211 с.

12. Про введення воєнного стану в Україні: Указ Президента України від 26 листопада 2018 р. № 393/2018 (Указ затверджено Законом № 2630-VIII від 26.11.2018 із застереженням). Голос Украӥни. 28.11.2018. № 226.

13. Про внесення змін до Конституції України (щодо стратегічного курсу держави на набуття повноправного членства 
України в Свропейському Союзі та в Організації Північноатлантичного договору): Закон України від 07.02.2019 р. № 2680-VIII. Офіщійний сайт Верховної Ради України. URL: https://zakon.rada.gov.ua/go/2680VIII.

14. Про національну безпеку України: Закон України від 21 червня 2018 р. № 2469-VIII. Відомості Верховної Ради Украӥни. 2018. № 31. Ст. 241.

15. Про рішення Ради національної безпеки і оборони України від 2 вересня 2015 року «Про нову редакцію Воєнної доктрини України»: Указ Президента України № 555/2015 від 24.09.2015. Офіиійний вісник Президента Украӥни. 2015. № 22. С. 19. Ст. 1291.

16. Современные международные отношения. Под. ред. А. В. Торкунова. Москва: Российская политическая энциклопедия (РОССПЭН), 1999. 584 с.

17. Теоретичні основи та елементи національної безпеки України. Ред. В. Ліпкана. Київ: Текст, 2003. 600 с.

18. Шевцов А. I. Майбутне людства необхідно спланувати: глобальні загрози і довгострокова стратегія розвитку України. Стратегічні пріоритети. 2007. № 1(2). С. 187-193.

19. Шерпаев В. И. Военная политика современной России. Екатеринбург: Изд-во Уральского университета, 2007. 171 с.

\section{Information about the author:}

Kormych A. I.,

$\mathrm{PhD}$ in History, Associate Professor, Associate Professor at the Department of General Jurisprudence of the National University «Odessa Law Academy» 2, Akademichna str., Odessa, 65009, Ukraine 